\title{
The Protestant Homiletics Approach toward Preaching on the Internet
}

The Internet causes billions of images to appear on millions of computer monitors around the planet. From this galaxy of sight and sound will the face of Christ emerge and the voice of Christ be heard? For it is only when His face is seen and His voice heard that the world will know the glad tidings of our redemption. This is the purpose of evangelization. And this is what will make the Internet a genuinely human space, for if there is no room for Christ, there is no room for man ${ }^{2}$

it is in these words that John Paul II expressed not only the attitude of the Church to this new (now omnipresent) medium, but also the sense of active presence of Christians on the Internet, whose origins date back to the 1990s. For both the Catholic Church and Protestant Churches, the global network is an important evangelistic tool, a transmitter of gospel truths. Today, 'there already exist on the Net countless sources of information, documentation and education about the Church, its history and tradition, its doctrine and engagement in every field in all parts of the world' ${ }^{3}$. One can find on the Web various forms of preaching the word of God in all languages and in an unimaginable quantity. There are sermons,

\footnotetext{
${ }^{1}$ Adam Kalbarczyk - priest of the Archdiocese of Poznań, PhD with a postdoctoral degree in theology, Associate Professor of homiletics at the Faculty of Theology of Adam Mickiewicz University in Poznan; member of the Society of Friends of Science in Poznań; German philology specialist, translator; author of several books and articles on pastoral theology and theology of preaching; his interests focus on homiletic rhetoric, the so-called 'children's theology', the relationship between the theatre and preaching, the ministry of the word by the laity, and the history of Protestant preaching in the period of Lutheran orthodoxy; e-mail: adamkal@amu.edu.pl. ORCID: 0000-0002-3749-2497.

2 John Paul II, Message for the 36th World Communications Day 2002, 6.

3 Ibidem 2.
} 
catecheses, meditations, retreats, etc. - there are texts, sound and video recordings or live broadcasts ${ }^{4}$. The presence of preaching on the Internet poses serious challenges to modern theology and demands theological interpretation and classification. As far the evangelical aspect is concerned, one has long heard voices that traditional homiletics is not able to meet these challenges. These voices have initiated a discussion on the need to create a new homiletics for the Internet. This article will present a framework for such homiletics. Since it relies heavily on the paradigm of sermon as an 'open work of art' adopted from Gerhard M. Martin's aesthetic homiletics, the first part of the article will focus on his concept. The second part will be devoted to ecclesiological issues, without which it is impossible to fully grasp the reality of preaching in cyberspace. Both parts of the article will be preceded by a short presentation of one of the functions of the global network which is essential to the proposed concept of homiletics for the Internet.

\section{The Internet as a simulation medium}

Currently, we use the Internet in five different ways. Each of them is associated with different forms of expression of the so-called cyberculture. The Web is used as a source of information (knowledge on demand), a medium of communication in society (bi- and multilateral exchange), a cooperation instrument (knowledge creation alliances), a means of presentation (sharing knowledge and self-presentation) and a simulation tool ${ }^{5}$. As far as the latter applications are concerned, we can talk about a specific internet 'simulation culture' whose strength lies in the possibility of the approximate, artificial and model-based reproduction of phenomena, behaviours, something that is missing, or creating, posing and marking something new, e.g. science fiction worlds, alternative cultural forms, dream lands, 'neverlands', religious imaginations, etc $^{6}$. In terms of its potential for simulating something new, the Internet reveals its not yet fully theologically investigated ability to transcend, i.e. to cross space and time on a global scale.

\footnotetext{
${ }^{4}$ See: Ł. Konatowski, Przepowiadanie w Internecie - na przykładzie Chrześcijańskiego Serwisu 'Mateusz', Poznań 2009 [Master's thesis, Faculty of Theology, Adam Mickiewicz University], pp. 40-87.

${ }_{5}^{5}$ See: S. Bobert-Stützel, Verkündigung im Internet? Befund und Problematik, 'Diakonia' 6 (2000), p. 418. Cf. J. Becker, M. Thygs, Internetentwicklung und Entwicklung im Internet, 'Informationes Theologiae Europae' 13 (2004), pp. 191-204.

${ }^{6}$ See: T. Walczyk, Bomba symulakrów - scena rzeczywistości ukryta za kultura symulacji. Spektakl hiperrzeczywistości, 'Humanistyka i Przyrodoznawstwo' 21 (2015), pp. 197-199, 202 204. Cf. Ł. Kapralska, Wirtualne państwa - zabawa, nostalgia, utopia, in: Nie tylko Internet. Nowe media, przyroda i 'technologie spoleczne' a praktyki kulturowe, red. J. Mucha, Kraków 2010, pp. 65-75.
} 
However, what Churches most often provide in virtual space is a simulation of what has already been available in existing real parishes or churches. Especially, the simulation of liturgy in cyberspace reveals the weak side of this medium because in the sphere of what is the most important in liturgy and what enables its participants to experience transcendence, i.e. physicality, sensoriness, directness, intimacy and openness, the Web usually offers merely a sterile substitute.

\section{Sermon as an 'open work of art'}

The situation is not different with the simulation of preaching in cyberspace. Therefore, many ministers and theologians are asking today how to make the most out of the power of the Internet in order to use it as a simulation tool for an online sermon. In answer to this question, some Protestant preaching theorists postulate a new outlook on the phenomenon of sermon as an open reality, open to the world of hearers, not closed until it is received and confirmed by the other party as relevant and also as an opening reality, opening the ears and hearts of hearers, opening to transcendence (going beyond one's own life context), opening heaven ${ }^{7}$. Expanding their postulate, these authors quite readily dwell on the concept of sermon developed by Gerhard M. Martin, an Evangelical theologian and one of the fathers of the German Bibliodrama. This concept, devised in the world without the omnipresent Internet, is referred to as an 'open work of art'

Gerhard M. Martin, referring to research on the phenomenon of the sermon conducted in the second half of the twentieth century by such Protestant theologians as Karl W. Dahm or Ernst Lange (1927-1974), and based mainly on communication theory, found their desiderates to be correct in theory, yet not feasible in practice. He, therefore, stated that homiletics needed a new model which, as he mantained, was an aesthetics paradigm. That is why, he suggested looking at the phenomenon of the sermon through the lens of the so-called aesthetic of reception ${ }^{9}$. He referred to the notion of an open work, i.e. a proposal for interpretation,

7 See: A. Beutel, Offene Predigt. Homiletische Bemerkungen zu Sprache und Sache, 'Pastoraltheologie' 77 (1988), pp. 518-519; K.H. Bieritz, Offenheit und Eigensinn. Plädoyer für eine eigensinnige Predigt, in: Predigt als offenes Kunstwerk. Homiletik und Rezeptionsästhetik, hrsg. v. E. Garhammer, H.G. Schöttler, München 1998, pp. 28-50.

${ }^{8}$ See: G.M. Martin, Predigt als 'offenes Kunstwerk'?, 'Evangelische Theologie' 44 (1984), pp. 46-58.

9 The term proposed in the 1960s by Hans R. Jauss (1921-1997) and his school, expressing a new literature studies paradigm, a methodological proposal in literature theory - in place of the so-called production and manufacturing aesthetics. See: H.R. Jauss, Historia literatury jako wyzwanie rzucone nauce o literaturze (fragmenty), thum. R. Handke, 'Pamiętnik Literacki' 4 (1972), pp. 271-307. Cf. E. Garhammer, 'Boomt jetzt die Ästhetik?’ Homiletik und Rezeptionsäs- 
analysis of each work of art as an open work described in 1962 by the famous Italian semiologist, medievalist and novelist Umberto Eco (1932-2016). This openness does not depend - as emphasized by Eco - on the intention of the author of the work, but on the approach of the recipient who interprets the work ${ }^{10}$.

According to Martin, the model proposed by Eco allows for a more adequate grasp of the reception process of a particular sermon as it allows to explore the structure of this process, which is inherently multi-faceted and open to a virtually infinite string of possible ways of interpretation ${ }^{11}$. It is in this way - Martin says - one should look at the preaching process. In the course of its reception by hearers, 'a word for all' may assume various specific 'forms' giving each of them an opportunity to include in the sermon process their current situation, their personal life context, thus becoming 'a word for me'. In this respect, the preacher's task would be to create a wide space for a series of various possibilities consisting not only in his suggestion of the relationship of the word of God with the "here and now' of hearers, but also 'encouraging' them to 'active listening' through additional questions, short pauses, meditation, appealing to imagination, etc.

Martin's concept allowed to look at the communication process of preaching from a new perspective and stimulated both preachers and hearers to cooperation and mutual inspiration. It emphasizes the autonomy of hearers and in some sense 'relieves' preachers. Above all, it defends the sovereignty of hearers in the process of interpreting the word of God against the temptations of complete control over the process by preachers.

Albrecht Beutel, a professor of evangelical theology at the University of Münster, made a critical analysis of Martin's concept claiming that Martin's homiletic intention was not to put a sermon in the 'open work of art' model, although Eco actually allowed any work of art to be included in it, but above all enabling and learning a renewed, 'open' preaching and listening to sermons, which is what Eco called a work of art in motion' ${ }^{12}$. Thus, ultimately, according to Beutel, Martin's concept is a call for both preachers and hearers to be active, to listen actively, to situate and interpret their lives, their world and their history in the light of the Gospel.

Continuation of Martin's thought can be seen in the semiotically directed homiletics of Wilfried Engemann, a German evangelical theologian from Vienna,

thetik, in: Predigt als offenes Kunstwerk. Homiletik und Rezeptionsästhetik, hrsg. v. E. Garhammer, H.G. Schöttler, München 1998, pp. 13-27.

${ }^{10}$ U. Eco, Dzieło otwarte. Forma i nieokreśloność w poetykach wspótczesnych, thum. A. Sawisz, Warszawa 2008.

${ }^{11}$ See: G.M. Martin, Predigt..., pp. 49-50. Cf. idem, Zwischen Eco und Bibliodrama. Erfahrungen mit einem neuen Predigtansatz, in: Predigt als offenes Kunstwerk. Homiletik und Rezeptionsästhetik, hrsg. v. E. Garhammer, H.G. Schöttler, München 1998, pp. 51-62; H. Schröer, Umberto Eco als Predigthelfer?, 'Evangelische Theologie' 44 (1984), pp. 58-63.

12 See: A. Beutel, Offene Predigt..., pp. 522-523. 
who, like Martin, opposes the so-called 'homiletic myths' about the 'inviolability' of the preacher, 'independence' of the biblical message and 'incompetence' of the hearer in the process of preaching the word of God as well as temptations (present in his opinion primarily in kerygmatically-shaped homiletics) of limiting semantic connotations and such theological 'sealing' of the sermon content as to make its addressees listen to it as 'unanimously' as possible ('obstructive' preaching). On the other hand, the preacher is required to possess a certain dose of aesthetic sensitivity allowing for such a multidimensional presentation of the biblical text in a sermon that it remains wide open to other ways of reading (the so-called 'generated multiple-meaning utterance'). In this sense, Engemann's semiotic homiletics appears to be a kind of refinement of Gerhard M. Martin's aesthetic concept ${ }^{13}$. One can take a similar look at homiletic reflection and interpretative constructions of texts by Hartmut Raguse, a well-known evangelical christologist, biblist and psychoanalyst from Basel ${ }^{14}$.

\section{Homiletics for the Internet}

At the beginning of the $21^{\text {st }}$ century, a new understanding of ecclesial preaching following an aesthetic of reception and related sermon model as an 'open work of art' proposed by Marcel became the basis for an innovative concept of 'homiletics for the Internet' (Homiletik für das Internet), sometimes also called 'internet homiletics' or 'homiletics of the Internet' (Internet-Homiletik or Netzhomiletik). Its creators noticed that a sermon placed in cyberspace could be an 'open work of art or a work of art in motion' on a scale Martin could not have predicted when formulating his homiletics postulates. The Web, like no other means of communication can provide a sermon to listeners - especially through the culture of simulation - with a wide open space for spontaneous reactions, associations and emotional reception, as well as enabling their situation to be included in the sermon process. Sabine Bobert-Stützel, a theologian from Kiel, believes that an absolutely new approach is needed for preaching on the Web. It would primarily consist in bidding farewell to the kerygmatic and communication theory paradigm, with which the current homiletics tries to 'control' the processes of preaching and the flow of preaching content on the Internet - similarly to how road transport inspection supervises the flow of goods - ensuring that there are no disruptions and breaking the rules in preaching the message of salvation and in communication between the preacher and the recipient (mainly whether the message received by the recipient exactly matches the message composed

\footnotetext{
${ }^{13}$ See: W. Engemann, Semiotische Homiletik, Tübingen-Basel 1993.

${ }^{14}$ See: S. Bobert-Stützel, Frömmigkeit und Symbolspiel, Göttingen 2000, p. 340 ff.
} 
and relayed by the communicator). Homiletics for the Internet must, in her view, develop a new understanding of concepts such as 'message', 'coding' and 'decoding'. Bobert-Stützel also advises to accept the fact that the Internet creates a huge space for the freedom and diversity of reception of preached content and wants any 'interference' to be treated - like Martin does — as 'the freedoms of human communication' (Freiheiten der menschlichen Kommunikation), for which, as Martin said, human existence, its biographical and social contexts will always be a natural border ${ }^{15}$. Ultimately, it is in them that man meets and enters into dialogue - also via the Web - with the living and effective word of life. What is important is the question whether the word of God contained in a sermon creates spaces for individual assimilation in the hearer's specific life situation. This approach should help the preacher avoid impractical and banal content in sermons as well as recognizing and appreciating the interpretative competence of hearers ${ }^{16}$. The Internet seems to create special conditions for this.

\section{Ecclesiology for preaching on the Internet}

What kind of understanding of the Church accompanies such formulated homiletics for the Internet? One cannot think about any homiletics without referring to ecclesiology and, above all, without answering the question about the relationship between preaching the word of God and the Church ${ }^{17}$. According to Catholic theology, the Church is the subject (second to God) of preaching the word of God. The word of Christ remains in the word of the Church. The Church was built by the power of this word and is growing through it. Hence, the proclamation of the word of God by the Church 'is the first and basic function of its selfrealization' ${ }^{18}$ - therefore, it has an ecclesiogenic character. For Evangelicals, the Church is 'a community gathered around the Word of God'. It is born 'through the announced Word of God' and is created 'through an act of worship'. Without preaching, the Church would be 'one of many venerable institutions and would essentially not differ from charities or special interest groups. There is no Church without the Word of God, which is why Luther, followed by other reformers,

15 See: S. Gehrig, Leserlenkung und Grenzen der Interpretation. Ein Beitrag zur Rezeptionsästhetik am Beispiel des Ezechielbuches, Stuttgart 2013, pp. 14-18.

16 See: S. Bobert-Stützel, 'The medium is the message'. Zum medialen Wandel der Predigt im Internet, 'Magazin für Theologie und Ästhetik' 7 (2000), https://www.theomag.de/07/sbs1.htm [access: 14.05.2020].

17 See: S. Dyk, Relacja między przepowiadaniem słowa Bożego a Kościołem, 'Kieleckie Studia Teologiczne' 7 (2008), pp. 27-42.

18 H. Sławiński, Podmiot przepowiadania słowa $w$ liturgii, in: Liturgia i przepowiadanie, red. W. Przyczyna, Kraków 2010, p. 97. Cf. Z. Adamek, Homiletyka, Tarnów 1992, pp. 76-77. 
called the Church the creation of the Word of God (creatura verbi) ${ }^{19}$. Starting from these two very similar interpretations of the relationship between preaching and the Church, one needs to ask whether the Church's proclamation of the word of God on the Internet is community-forming, and if so, whether communities emerging as a result of it are ecclesial in their character.

One can assume that the very act of sharing the word of God on the Web already has an ecclesial dimension because the homiletic 'offer' of the Internet is usually backed by real parishes or church communities, orders and congregations, people of the Church, specific ministers, preachers, retreat givers, etc. It is often addressed to specific communities, to those who participate in their life on a daily basis, but also to all those who distance themselves and keep seeking. Therefore, it aims to either strengthen the sense of belonging to the community of the Church or to invite to it in accordance with the Catholic Church's teaching related to the Internet, which although

can never replace that profound experience of God which only the living, liturgical and sacramental life of the Church can offer, it can certainly provide a unique supplement and support in both preparing for the encounter with Christ in community, and sustaining the new believer in the journey of faith which then begins ${ }^{20}$.

It is hard to resist the impression that ecclesial preaching on the Web promotes rather individual religiosity than ecclesiality. Is it not, then, supporting and strengthening the tendencies of individualization and networking in modern societies $^{21}$, which are reinforced by the Internet? This question is all the more important since at the end of the 1990s some evangelical theologians heralded a prompt disappearance of the local Church and the birth of the 'cyber church': 'The day is coming when people will no longer want to take direct part in the life of the local community of the Church, preferring belonging to the virtual church ${ }^{22}$. Will it still, however, be the same Church? Do social structures and virtual communities formed on the basis of Internet communication have the features of ecclesiality?

Matthias Schnell, who at the turn of the $20^{\text {th }}$ and $21^{\text {st }}$ centuries managed the 'Church and the Internet' project in the German Evangelical Church (Kirche und Internet), believed that Christianity can be experienced within various

${ }^{19}$ Kościół po ewangelicku - jak luteranie rozumieją Kościót, http://luter2017.pl/ewangelickie-rozumienie-kosciola-eklezjologia/ [access: 15.05.2020].

${ }^{20}$ John Paul II, Message..., 2.

${ }^{21}$ The form of social organization in which an individual, not a place, structures or institutions, becomes the axis around which human relationships are arranged. See: M. Juza, Między wolnościa a nadzorem. Internet w zmieniającym się spoleczeństwie, Warszawa 2019, pp. 86-88.

${ }^{22}$ H.N. Janowski, Vorwort, in: Cyberchurch? Kirche im Internet, hrsg. v. W. Nethöfel, M. Schnell, Frankfurt am Main 1998, p. 8. 
social structures and they do not have to be institutionalized forms imposed by Churches. Referring to this statement, Sabine Bobert-Stützel proposes for the Internet a model of the 'open People's Church' (offene Volkskirche), open wide to all those surfing on the web, including those who want to bring their own theologies to it or formulate them there, treating them very individually as fully-fledged entities, capable of independent interpretation and reception of what the Internet offers them in the range of Christian faith ${ }^{23}$.

The concept of an 'open sermon' for the 'open Church' on the Internet seems to indirectly prove the ecclesiality of virtual communities gathering around the word of God on the Web. Ulrich Nembach, a professor of practical theology at the University of Göttingen, sought a direct answer to the question about the ecclesiality of these communities referring to his experience and research on the so-called Göttinger Predigten. This is an internet portal edited by him and Johannes Neukirch in 1997-2006 $6^{24}$ offering free sermon texts for Sundays and feasts according to the evangelical liturgical calendar or specific biblical texts. The site has been very popular, usually providing several sermons for a given Sunday in four languages: German, English, Portuguese and Danish. They are prepared by over 350 authors from all over the world. Some of the authors have been cooperating with the portal for many years. The portal users can express themselves in a freely accessible visitor $\log$, which gives an insight into the complex structures of interrelationships resulting from the use of this website. It reveals not only the opinions, ideas and interests of website visitors, but also whether the content it offers is close or distant to them as well as the nature of their mutual relations ${ }^{25}$. Nembach, therefore, raises a question of the essence of the community that is formed around Göttinger Predigten, the community of text writers and people using them. Is it a kind of virtual community - like communities created by authors and readers of printed magazines? Is it a church community — similar to that born through preaching the word of God? Esko Ryökäs, a Finnish Lutheran theologian, answered this question in the affirmative. In order to describe these realities, he used methods developed by sociology and referred

${ }^{23}$ See: S. Bobert-Stützel, 'The medium... Cf. K. Fechtner, Religiöser Individualismus und Kirche. Praktisch-theologische Perspektiven im Anschluss an Ernst Troeltsch, in: Religion in der Lebenswelt der Moderne, hrsg. v. K. Fechtner, M. Haspel, Stuttgart 1998, pp. 208-226; idem, Den Zeitgenossen Kirche sein. Plädoyer für eine offene Volkskirche, 'Deutsches Pfarrerblatt' 5 (1996), pp. 235-238.

${ }^{24}$ Currently, the editor-in-chief of the portal is Thomas Schlag, an Evangelical theologian and professor of practical theology at the University of Zurich. See: http://www.theologie.uzh.ch/predigten/ [access: 10.06.2020].

${ }^{25}$ See: U. Nembach, Internethomiletik - eine faszinierende neue Disziplin. Am Beispiel der Göttinger Predigten dargestellt, 'Evangelische Theologie' 5 (2006), p. 395. Cf. D. Ludwig, Theologie online. Die Göttinger Predigten im Internet und ihre Besucher. Momentaufnahme eines relationalen Geschehens, 'Informationes Theologiae Europae' 10 (2001), pp. 79-117. 
critically to the concept of church community from the old Lutheran dogmatics. He observed that it reflected social relations prevailing in the $16^{\text {th }}$ century (similarly to social conditions being manifested in the New Testament images of Christian communities). Luther referred the concept of church community to a local community (parish). However, through his writings, especially postils, he went far beyond their local borders. Therefore, today's situation allows to treat the Internet not only as a medium, but also as a place where the Church community becomes a reality ${ }^{26}$. According to Ryökäs, the community gathered around a sermon on the Internet is an ecclesial community ${ }^{27}$.

$$
* * *
$$

Protestant theology began to reflect on the meaning and form of preaching on the Internet that would allow to transcend space and time globally already in the very early years of the Web. It was quickly recognized that the theological approach to this very diverse and always open reality requires a new, renewed, different homiletics for the Internet as theology - directed at the local community of the Church gathering during liturgy - can only be helpful here to a limited extent. The external conditions of the internet community and local community are different. Nevertheless, in both cases we deal with a degree of sacredness and spirituality. In both communities, formal conditions - even if only partially — are met: here and there we deal with the well- and less-informed, young and old, women and men, intellectuals and simple souls, etc. Each sermon, including a virtual one, must take all of these people into account. Liberating consolation (Zuspruch) and claim (Anspruch), teaching and admonishment (Lehren und Ermahnen) - according to the rule given by Luther, are also done on the Internet. An Internet sermon maintains the character of a sermon, the preacher and hearer meet essentially in the known area, i.e. as in a church, creating a community — though virtual — but still an ecclesial one.

According to the Protestant approach presented here, describing and creating the reality of preaching on the Internet requires not only a new homiletics, but also a new ecclesiology, which uses - although it is difficult to accept in Catholic theology - a very broadly defined, capacious, and open concept of the church community, transferred to technology, on a medium, which has undergone a kind of theological, sacralized and ecclesial change. Such ecclesiology was the basis for the concept of a new homiletics, which used - also difficult

${ }^{26}$ This position seems to have been shared by the Evangelical Church in Germany (EKD) for many years.

27 E. Ryökäs, Predigtgemeinschaft im Internet - eine Kirchengemeinschaft?, 'Informationes Theologiae Europae' 8 (1999), pp. 339-352. 
to accept by Catholic theology - a largely de-kerygmatized, de-theologized and non-ecclesial concept of an open sermon, a sermon wide open to the Web listener, very important in the process of preaching, though highly sacralised here.

Finally, a question should be asked whether a sermon on the Internet - in the form of texts, sound and video recordings, or even live broadcasts - is still a sermon. Catholic theology - for which a sermon, especially a homily, is a salvific event, an encounter with the word of God taking place 'here and now', in direct contact between the preacher and the hearer - answers this question in the negative. Therefore, since we do not deal with authentic church preaching in the virtual space, the question arises whether what is considered to be the act of preaching in it should be the subject of homiletics-related research at all. Is this not a task for media theology?

\section{Summary}

The presence of the sermon in cyberspace requires an in-depth theological interpretation and an appropriate classification. Evangelicals maintain that traditional homiletics is not able to meet this new technological challenge, thereby they call for creating a new homiletics, i.e. the one crafted for the Internet. This article outlines the proposal of such homiletics and discusses it thoroughly. This new approach toward Gospel preaching stems from the paradigm which perceives the sermon as an 'open work of art', adopted from Gerhard M. Martin's aesthetic homiletics. Its supporters claim that the current situation allows for considering the Internet not only as a medium, but also a place where the Church is realized. Thus, the community gathered online around the sermon is treated as an ecclesial community. However, the Catholic Church does not accept such an understanding of both the Church and the sermon. In their view, in a virtual space the authentic preaching of the Church cannot be performed. Therefore, all forms of preaching on the Internet should not be researched by homiletics, but media theology.

\section{Keywords}

homiletics, Protestant theology, sermon, Internet

\section{Homiletyka protestancka wobec kazania w Internecie}

\section{Streszczenie}

Obecność kazania w cyberprzestrzeni domaga się teologicznej interpretacji i klasyfikacji. Po stronie ewangelickiej panuje przekonanie, że tradycyjna homiletyka nie jest w stanie sprostać temu wyzwaniu, dlatego trzeba stworzyć nową homiletykę, homiletykę dla Internetu. Niniejszy artykuł omawia propozycję takiej homiletyki. Opiera się ona w dużej mierze na paradygmacie kaza- 
nia jako „otwartego dzieła sztuki”, przejętego z homiletyki estetycznej Gerharda M. Martina. Propozycji tej towarzyszy też przekonanie, że dzisiejsza sytuacja pozwala na traktowanie Internetu nie tylko jako medium, lecz także miejsca, w którym urzeczywistnia się Kościół. Wspólnotę gromadzącą się wokół kazania w sieci traktuje się więc jako wspólnotę kościelną. Takiego rozumienia zarówno Kościoła, jak i kazania nie akceptuje strona katolicka, według której w przestrzeni wirtualnej nie mamy do czynienia z autentycznym kościelnym przepowiadaniem. Wszelkie formy kaznodziejskie w Internecie nie powinny być zatem przedmiotem badań homiletyki, lecz teologii mediów.

\section{Slowa kluczowe}

homiletyka, teologia protestancka, kazanie, Internet

\section{Bibliography}

Adamek Z., Homiletyka, Tarnów 1992.

Becker J., Thygs M., Internetentwicklung und Entwicklung im Internet, 'Informationes Theologiae Europae' 13 (2004), pp. 191-204.

Beutel A., Offene Predigt. Homiletische Bemerkungen zu Sprache und Sache, 'Pastoraltheologie' 77 (1988), pp. 518-537.

Bieritz K.H., Offenheit und Eigensinn. Plädoyer für eine eigensinnige Predigt, in: Predigt als offenes Kunstwerk. Homiletik und Rezeptionsästhetik, hrsg. v. E. Garhammer, H.G. Schöttler, München 1998, pp. 28-50.

Bobert-Stützel S., Frömmigkeit und Symbolspiel, Göttingen 2000.

Bobert-Stützel S., 'The medium is the message'. Zum medialen Wandel der Predigt im Internet, 'Magazin für Theologie und Ästhetik' 7 (2000), https://www.theomag. de/07/sbs1.htm.

Bobert-Stützel S., Verkündigung im Internet? Befund und Problematik, 'Diakonia' 6 (2000), pp. 416-419.

Dyk S., Relacja między przepowiadaniem słowa Bożego a Kościołem, 'Kieleckie Studia Teologiczne' 7 (2008), pp. 27-42.

Eco U., Dzieło otwarte. Forma i nieokreśloność w poetykach wspólczesnych, tłum. A. Sawisz, Warszawa 2008.

Engemann W., Semiotische Homiletik, Tübingen-Basel 1993.

Fechtner K., Den Zeitgenossen Kirche sein. Plädoyer für eine offene Volkskirche, in: 'Deutsches Pfarrerblatt' 5 (1996), pp. 235-238.

Fechtner K., Religiöser Individualismus und Kirche. Praktisch-theologische Perspektiven im Anschluss an Ernst Troeltsch, in: Religion in der Lebenswelt der Moderne, hrsg. v. K. Fechtner, M. Haspel, Stuttgart 1998, pp. 208-226.

Garhammer E., 'Boomt jetzt die Ästhetik?' Homiletik und Rezeptionsästhetik, in: Predigt als offenes Kunstwerk. Homiletik und Rezeptionsästhetik, hrsg. v. E. Garhammer, H.G. Schöttler, München 1998, pp. 13-27. 
Gehrig S., Leserlenkung und Grenzen der Interpretation. Ein Beitrag zur Rezeptionsästhetik am Beispiel des Ezechielbuches, Stuttgart 2013.

Janowski H.N., Vorwort, in: Cyberchurch? Kirche im Internet, hrsg. v. W. Nethöfel, M. Schnell, Frankfurt am Main 1998, p. 8.

Jauss H.R., Historia literatury jako wyzwanie rzucone nauce o literaturze (fragmenty), thum. R. Handke, 'Pamiętnik Literacki' 4 (1972), pp. 271-307.

John Paul II, Message for the 36th World Communications Day 2002, 6.

Juza M., Między wolnościa a nadzorem. Internet w zmieniającym się społeczeństwie, Warszawa 2019.

Kapralska Ł., Wirtualne państwa - zabawa, nostalgia, utopia, in: Nie tylko Internet. Nowe media, przyroda i 'technologie społeczne' a praktyki kulturowe, red. J. Mucha, Kraków 2010, pp. 65-75.

Konatowski Ł., Przepowiadanie w Internecie - na przykładzie Chrześcijańskiego Serwisu 'Mateusz' [Master's thesis, Faculty of Theology, Adam Mickiewicz University], Poznań 2009.

Kościót po ewangelicku — jak luteranie rozumieją Kościół, http://luter2017.pl/ewangelickie-rozumienie-kosciola-eklezjologia/.

Ludwig D., Theologie online. Die Göttinger Predigten im Internet und ihre Besucher. Momentaufnahme eines relationalen Geschehens, 'Informationes Theologiae Europae' 10 (2001), pp. 79-117.

Martin G.M., Predigt als 'offenes Kunstwerk'?, 'Evangelische Theologie' 44 (1984), pp. 46-58.

Martin G.M., Zwischen Eco und Bibliodrama. Erfahrungen mit einem neuen Predigtansatz, in: Predigt als offenes Kunstwerk. Homiletik und Rezeptionsästhetik, hrsg. v. E. Garhammer, H.G. Schöttler, München 1998, pp. 51-62.

Nembach U., Internethomiletik - eine faszinierende neue Disziplin. Am Beispiel der Göttinger Predigten dargestellt, 'Evangelische Theologie' 5 (2006), pp. 394-399.

Ryökäs E., Predigtgemeinschaft im Internet - eine Kirchengemeinschaft?, 'Informationes Theologiae Europae' 8 (1999), pp. 339-352.

Schröer H., Umberto Eco als Predigthelfer?, 'Evangelische Theologie' 44 (1984), pp. 58-63.

Sławiński H., Podmiot przepowiadania słowa w liturgii, in: Liturgia i przepowiadanie, red. W. Przyczyna, Kraków 2010, pp. 93-112.

Walczyk T., Bomba symulakrów - scena rzeczywistości ukryta za kultura symulacji. Spektakl hiperrzeczywistości, 'Humanistyka i Przyrodoznawstwo' 21 (2015), pp. 195-208. 